\title{
岩石のクリープ試験における周ひずみの 挙動に関する研究*
}

\author{
藤 井 義 明 $^{1}$ 木 山 保 $^{2}$ \\ 大 森 瑞 穂 $^{3}$ 石 島 洋 二 ${ }^{4}$
}

\section{A Study of the Behaviors of Circumferential Strain in Creep Tests on Rock}

by Yoshiaki FUJII ${ }^{1}$, Tamotsu KIYAMA ${ }^{2}$, Mizuho OMORI ${ }^{3}$ and Yoji ISHIJIMA ${ }^{1}$

1. Faculty of Engineering, Hokkaido University, Kita-ku, Sapporo 060

2. Technical Research Institute, Mitsui Construction Co. Ltd., Komaki, Nagareyama-shi 270-01

3. Student, North East Surrey College of Technology, Nescot Epson Centre, Long Mead Road Epson Surrey, KT19, 9BH, UK

The behaviors of circumferential strain in creep tests on Inada Granite and Kamisunagawa Sandstone were investigated. The following tests, as well as conventional creep and constant strain rate tests, were carried out:

(1) Reloading tests were conducted by reloading at a constant strain rate in the way of the creep tests.

(2) Unloading tests were conducted by unloading when the peak load appeared in the way of the constant strain rate tests.

It was considered from the test results that (1) the points at which the magnitude of the circumferential strain rate reaches the minimum and the magnitude of the circumferential strain acceleration begins to increase are closely related to the point of maximum load in the constant strain rate tests, and (2) the magnitude of the circumferential strain could indicate the degree of rock damage in creep tests as well as in constant strain rate tests.

KEY WORDS : Rock, Creep, Circumferential Strain, Circumferential Strain Rate, Circumferential Strain Acceleration

\section{1. 緒}

\section{言}

鉱柱や坑道の長期安定性の評価に際しては, 岩石のクリープ挙 動を把握することが重要である。この見地から，これまでに，軸 ひずみや体積ひずみの挙動に注目した多くの研究がなされている。 たとえば, 西松・大久保 (1992) は, 単軸クリープ試験におけ る軸ひずみの 3 次クリープ特性に注目し, 鉱柱の寿命の予測法を 提案した。趙他（1995）は, 軸応力一軸ひずみ座標上で, クリー プ破壊の 10 秒前のデータが, 定ひずみ速度試験に扔ける強度破 壊点以降の応力ーひずみ曲線上に乗ることを示した。

山下他（1994）は，軸ひずみ速度が最小となる点（以下，軸ひ ずみ速度最小点と呼ぶ）に扔けるひずみ速度と同点に至るまでの 経過時間とが, 両対数グラフ上でほぼー1の傾きを持つ直線で近 似できることを示した。さらにYamashita et al.（1994）は， 同点の前後で再載荷を行い, 同点以前で再載荷を行った場合には

* 1996 年 7 月 5 日受付 12 月 20 日受理 資源・素材学会平成 6,7 年度春季 大会にて一部発表

1. 正会員 工博 北海道大学助手 工学部資源開発工学科

2. 正会員 三井建設(株)技術研究所主任研究員

3. 学生会員 North East Surrey College of Technology, UK

4. 正会員 工博 北海道大学教授 工学部資源開発工学科

〔著者連絡先〕FAX 011-706-6299（北大・資源）

キーワード：岩石，クリープ，周ひずみ，周ひずみ速度，周ひずみ加速度
定ひずみ速度試験で得られるのと等しい大きさの強度が現れるこ と, また, 同点以降で再載荷を行った場合には低下した強度が得 られることを明らかにした。

一方, Cogan (1976) は含水飽和した石灰岩等について封圧 下のクリープ試験を行い, 間隙水の流入出量から評価した体積ひ ずみに注目した。また，Kranz (1980) は，3 次クリープ開始点 における非弾性体積ひずみなる量に注目して，これが封圧ととも に増加することを示した。児玉他（1995）も非弾性体積ひずみに 注目している。

ところが, 西松・大久保 (1992) は, 鉱柱の寿命の予測に関し て, (1)岩石の一軸圧縮試験において, 軸ひずみよりも横ひずみ の方に微視的き裂の発生が敏感に現れる，(2)現場ではしばしば, 軸方向のひずみよりも横方向のひずみを測定する方が容易であり, 実際，安定性評価のために計測されているのは同方向のひずみな いしは変位である場合が多い, などの理由から, 、リープ時の横 ひずみの挙動の解明が今後の課題として残されていると述べてい 万。

クリープ試験時の横ひずみについては Singh（1975）がダイ ヤルゲージを用いて測定し, 軸ひずみと同様, 1 次, 2 次, 3 次 クリープを示すことを明らかにした。また, クリープ制御開始か らのひずみ変化量は，横方向の方が，軸方向よりも5 倍程度大き いことを示し，これは，比較的クリープ応力が大きい場合に共通 
してみられる現象であると述べている。

一方，筆者らは伸びひずみに基づいた岩石の破壊条件を提案し ており（藤井他，1994）, 限界引張ひずみ（最大荷重点における 周方向の伸びひずみの大きさ）が，封圧・載荷速度に依存せず， 含水状態に鈍感なこと（藤井・石島，1995）を示した。これは, 周ひずみの大きさが, 岩石の損傷程度をあらわすよい指標になり 得ることを示唆している。

本研究の目的は, Singh (1975) の研究を発展させ, 岩石のク リープ変形に扔ける周ひずみの挙動をより明らかにすることにあ る。このために, クリープ変形の過程において現れるいくつかの 特徵的な点に注目し, それらの点の工学的な意義について調査す る。

供試岩石として，花崗岩と砂岩を用い，周ひずみに注目して試 験結果を整理した。ただし，クリープ試験における負荷応力レベ ルは, 最長でも 2 日間以内で破壊に至るような大きさに限定した。 この場合，長期間のクリープに比べ実験上のさまざまな制約が少 ないので，載荷には材料試験機を，ひずみの測定には市販の計測 システムを用いた。周ひずみは, チェーン式周方向伸び計により 計測したが, 計測值は横ひずみの平均值を与えているものとし, また，ひずみゲージの使用に起因するさまざまな誤差を含まない と仮定して使用することにした（藤井他，1995）。

本研究では応力・ひずみは圧縮を正とする。このため, 周ひず みはほとんどの場合負になるが, グラフは,この約束に従ったこ とを断っておく。また，大小関係の比較にあたっては「大きさ (magnitude)」という言葉を「絶対值 (absolute value)」の意 味で用いた。

\section{2. 花崗岩のクリープ試験}

封圧下の載荷は, 最初, 周ひずみ速度一定制御で行い, 次に, 負荷応力一定のクリープ制御とし，3 次クリープが現れた後，再 度周ひずみ速度一定の制御に切り替えた。また, 通常の定ひずみ 速度の三軸圧縮試験も行い (木山他, 1994), 両載荷方法で得ら れた完全応力ーひずみ線図を比較した。

(a): relatively short-time creep
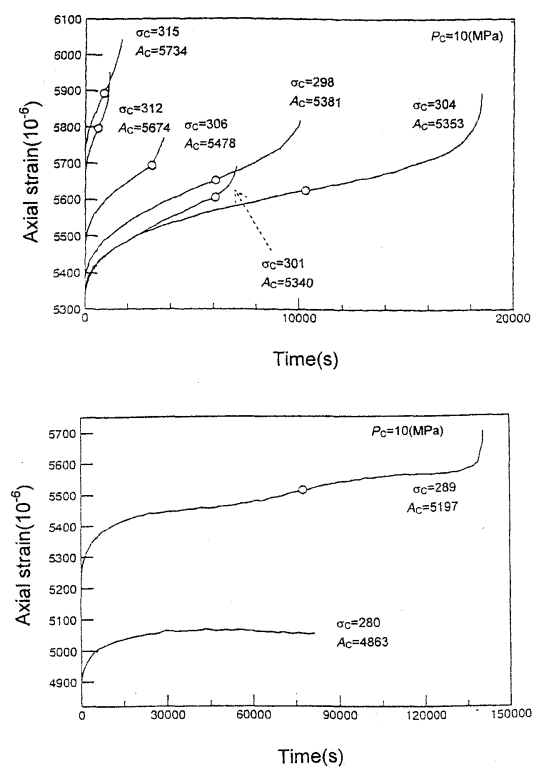

Fig. 1 Axial strain vs. elapsed time for Inada Granite under the triaxial creep tests. $P_{C}$ : confining pressure, $\sigma_{C}$ : creep stress in $\mathrm{MPa}, A_{C}$ : axial strain at the beginning of creep control in $10^{-6}, \bigcirc$ : points where the magnitude of the strain rate reaches the minimum.
試験結果の整理の際には，特に周ひずみ速度の大きさが最小に なる点や周ひずみ加速度の大きさが増加を開始する点に注目し， これらの点に至るまでの経過時間，これらの点に扮ける周ひずみ の大きさや周ひずみ速度等について検討することにした。

\section{$2 \cdot 1$ 供試体と試験方法}

ブロックで購入した茨城県笠間産の稲田花崗岩のリフト面に対 して垂直にコアボーリングし, 直径 $50 \mathrm{~mm}$, 長さ $100 \mathrm{~mm}$ に整 形した供試体を純水中に 1 か月以上浸した後, 収縮前の厚さ 0.3 $\mathrm{mm}$ のテフロン熱収縮チューブで被覆して実験に供した。

載荷にはMTS 社製 815 型岩石試験装置（定格荷重 4,600 kN, 最大封圧 $80 \mathrm{MPa}$ ，油圧サーボ式）を用い，軸ひずみはアクチュ エーターの変位から試験機の変形を差し引いて，また，周ひずみ は被覆の上から装着した同社製チェーン式周方向伸び計により評 価した。なお, 通常, 三軸試験では, 封圧載荷直後をひずみの基 準にとり，また，クリープ試験においては，しばしばクリープ制 御開始直後のひずみを 0 に取る。しかし，本研究では載荷前の大 気圧下に扔ける湿潤状態のひずみを 0 とした。含水による膨潤の 測定はしなかった。

封压は $10 \mathrm{MPa}$ と $20 \mathrm{MPa}$, 室内温度は $26 \sim 27{ }^{\circ} \mathrm{C}$ とした。軸 応力の載荷は, 最初, $-4.2 \times 10^{-6} / \mathrm{s}$ の一定周ひずみ速度で制 御し，周ひずみが $-1,500 〜-3,500 \times 10^{-6}$ に達したときにクリー プ制御に切り替えた。3 次クリープが始まり周ひずみ速度の大き さが $500 \times 10^{-6} / \mathrm{s}$ を越えた場合や，所定の時間内に 3 次クリー プが起こらない場合には, クリープ制御から, 再び周ひずみ速度 一定制御 $\left(-4.2 \times 10^{-6} / \mathrm{s}\right)$ に切り替えた。

データのサンプリング周波数は $100 \mathrm{~Hz}$ とし, クリープ載荷開 始後 100 秒間は $1 \mathrm{~Hz}$, 次の 9 秒間は $10 \mathrm{~Hz}$, クリープ制御終了 の 150 秒前までは $100 \mathrm{~Hz}$, 最後の 150 秒は $2 \mathrm{~Hz}$ のサンプリング 周波数に対応するデー夕のみハードディスクに記録した。

\section{$2 \cdot 2$ ひずみの経時変化}

封圧 $10 \mathrm{MPa}$ における軸・周ひずみの経時変化の例をそれぞれ Fig. 1，2 に示す。軸ひずみと同様，周ひずみも，1 次， 2 次， 3 次クリープを経て最終破断に至っている。封圧 $20 \mathrm{MPa}$ でも同様

(a): relatively
short-time short-time
creep

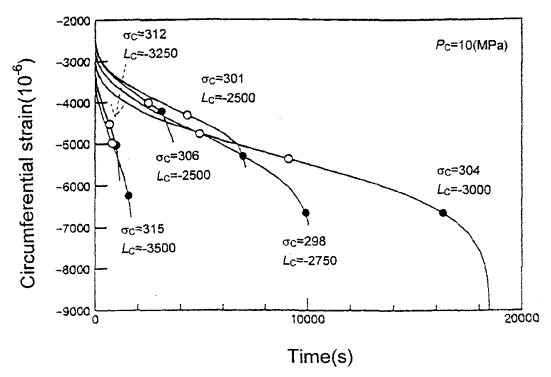

(b): relatively
long-term creep

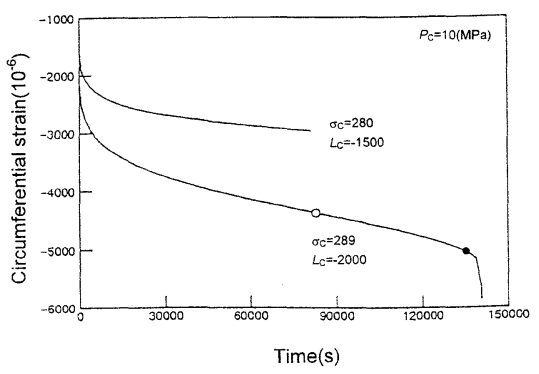

Fig. 2 Circumferential strain vs. elapsed time for Inada Granite. $L_{C}$ : circumferential strain at the beginning of creep con$L_{C}$ : circumferential strain at the beginning of creep con-
trol in $10^{-6}, 0$ : points where the magnitude of the strain rate reaches the minimum, : points where the acceleration magnitude begins to increase. 


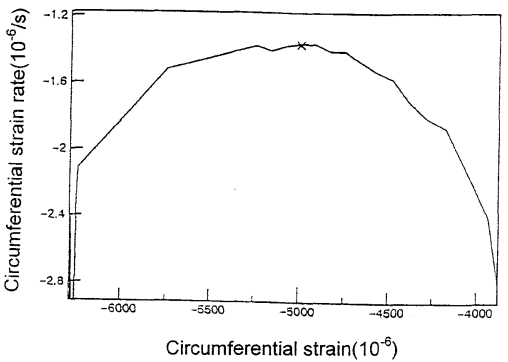

Fig. 3 Circumferential strain rate vs. circumferential strain for Inada Granite. $\times$ : point where the magnitude of the strain rate reaches the minimum.

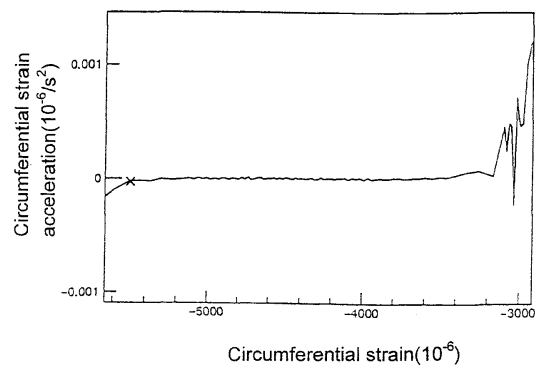

Fig. 4 Circumferential strain acceleration vs. circumferential strain for Inada Granite. $\times$ : point where the acceleration magnitude begins to increase.

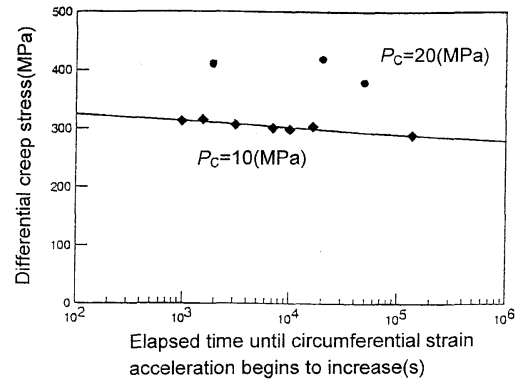

Fig. 5 Creep stress vs. elapsed time until the magnitude of the circumferential strain acceleration begins to increase for Inada Granite.
の挙動が観察された。

クリープひずみ（クリープ制御開始後のひずみ増分）の大きさ は，軸方向では数 $10^{-4}$ 程度なのに対し，周方向では数 $10^{-3}$ に 達しており，後者の方が約 10 倍大きい（Singh，1975の結果で は約 5 倍であった)。

\section{$2 \cdot 3$ 周ひずみ速度と周ひずみ加速度}

クリープ変形の過程では, 軸ひずみ速度が最小となる点のある ことがわかっている（たとえば大久保・西松，1986）が，周ひず みの経過時間に対する差分として定義される周ひずみ速度にも大 きさが最小になる点が存在する $(F i g .3)$ 。の点を, 以下では, 周ひずみ速度最小点と呼ぶ。周ひずみ速度最小点は軸ひずみ速度 最小点と同じく, 2 次クリープの中程に現れる。

周ひずみ速度の差分を取ると周ひずみ加速度が得られる (Fig. 4)。この值は, クリープ制御開始後, 変動しながら減少し, ほぼ 0 の状態をしばらく保った後, 急にマイナス側に増加する。 周ひずみ加速度の大きさがマイナス側に増加を開始する点を, 周 ひずみ加速度増加開始点と呼ぶ。この周ひずみ加速度増加開始点 とひずみ加速度がプラスからマイナスになる点であるひずみ速度 最小点とは必ずしも一致しない。実験の結果, 周ひずみ加速度増 加開始点はすべてのケースについて, ひずみ速度最小点の後に現 れた。

なお，軸方向のひずみについては $\mathrm{S} / \mathrm{N}$ 比が十分でなく，加速 度について信頼に足る評価を得るには至らなかった。この原因は, 軸方向のクリープひずみの大きさ・変位計の測定区間長がともに 周方向に比べて小さく, 計測される変位量が小さいためと考えら れる。

\section{$2 \cdot 4$ ひずみ速度最小点やひずみ加速度増加開始点の特徵}

(1)クリープ応力と両点までの経過時間＼cjkstart従来より，クリー プ応力と破断までの経過時間の対数との関係が, クリープ応力が 小さくない範囲内において，直線で近似できることが知られてい る。山下他（1994）は，破断までの経過時間の代わりに軸ひずみ 速度最小点に至るまでの経過時間を用いても同様の関係が成り立 つことを見出した。本研究では, 封圧が $20 \mathrm{MPa}$ の場合について はデータが少ないが, $10 \mathrm{MPa}$ の場合には山下他（1994）と同様 の結果が得られた。クリープ応力と周ひずみ速度最小点にいたる までの経過時間の対数との関係も封圧が $10 \mathrm{MPa}$ の場合について 直線で近似できた。軸ひずみ速度最小点までの経過時間と周ひず み速度最小点までの経過時間とはほぼ等しいので, 類似した関係 が成立するのは当然といえる。

さらに, 周ひずみ速度最小点に至るまでの経過時間の代わりに, 周ひずみ加速度増加開始点までの経過時間を用いても, クリープ 応力との間に同様の関係が得られることがわかった（Fig. 5)。

(2)ひずみ速度の最小值とひずみ速度最小点までの経過時間

軸ひずみ速度の最小值と軸ひずみ速度最小点までの経過時間と の関係は, 両対数座標上において傾きがほぼ-1の直線で近似さ れる（Fig. 6)。この関係は, 本文1。で述べた山下他（1994） の得た関係と同じであるが, 封圧にほとんど依存していないこと が注目される。

周方向についても同様の結果が得られた（Fig. 7)。ただし， 軸方向に比べ測定值のばらつきが少ないこと, ひずみ速度の最小 值は軸方向で $10^{-9} \sim 10^{-7} / \mathrm{s}$ であるのに対し, 周方向では $10^{-8}$ 〜 10 -6/sであり, クリープひずみの大きさと同様，後者の方が

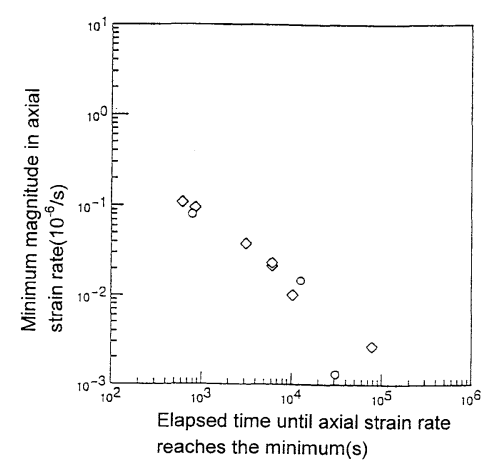

Fig. 6 The minimum magnitude of the axial strain rate vs. elapsed time until the magnitude of strain rate reaches the minimum for Inada Granite. Symbols $\diamond$ and $\bigcirc$ denote the confining pressures of 10 and $20 \mathrm{MPa}$, respectively.

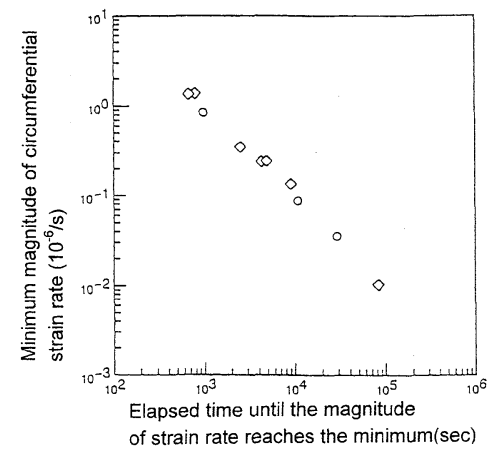

Fig. 7 The minimum magnitude of the circumferential strain rate vs. elapsed time until the magnitude of the strain rate reaches the minimum for Inada Granite. Symbols $\diamond$ and $\bigcirc$ denote the confining pressures of 10 and $20 \mathrm{MPa}$, respectively.

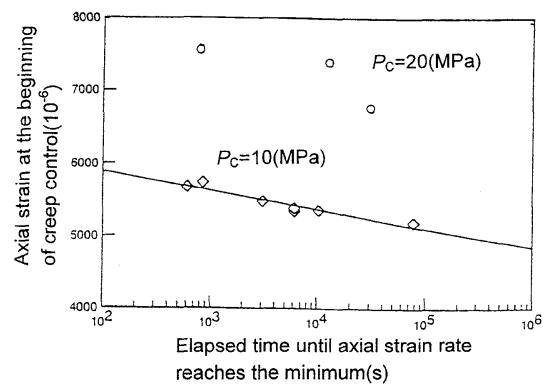

Fig. 8 Axial strain at the beginning of creep control vs. elapsed time until the axial strain rate reaches the minimum for Inada Granite. 


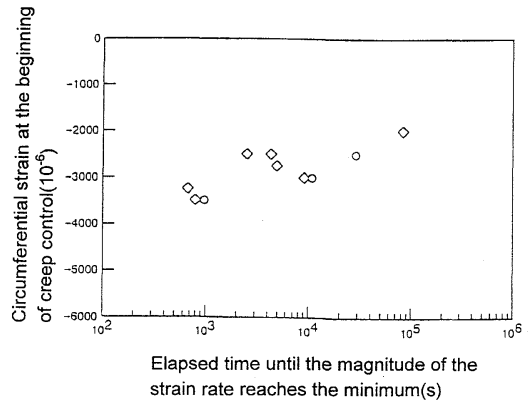

Fig. 9 Circumferential strain at the beginning of creep control vs elapsed time until the magnitude of the strain rate reaches the minimum for Inada Granite. Symbols $\diamond$ and $O$ denote the confining pressures of 10 and $20 \mathrm{MPa}$, respectively.

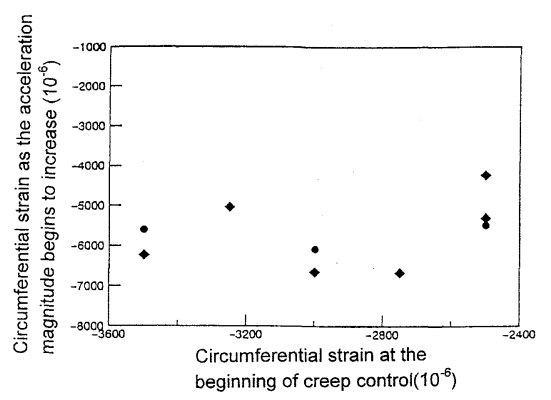

Fig. 12 Circumferential strain at the beginning of creep control vs. circumferential strain as the acceleration magnitude begins to increase for Inada Granite. Symbols and denote the confining pressures of 10 and $20 \mathrm{MPa}$, respectively.

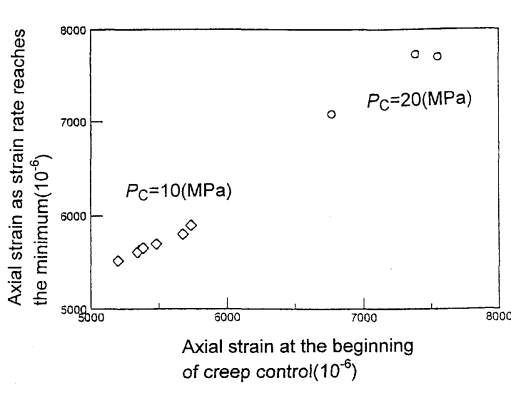

Fig. 10 Axial strain at the beginning of creep control vs. axial strain as the magnitude of the strain rate reaches the minimum for Inada Granite.

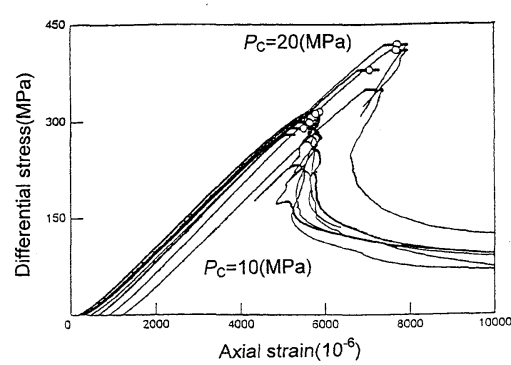

(a)

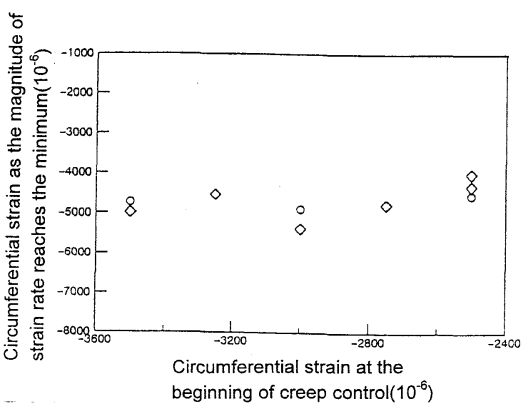

Fig. 11 Circumferential strain at the beginning of creep control vs. circumferential strain as the magnitude of the strain rate reaches the minimum for Inada Granite. Symbols $\diamond$ and $\bigcirc$ denote confining pressures of 10 and $20 \mathrm{MPa}$, respectively.

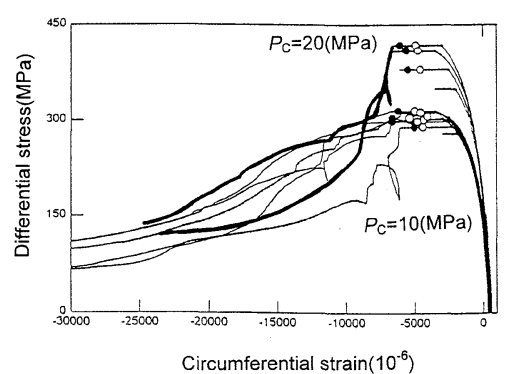

(b)
Fig. 13 Differential stress-axial (a) and circumferential (b) strain curves for Inada Granite in the triaxial creep tests. Thick lines denote circumferential strain in the post-peak region under a confining pressure of $20 \mathrm{MPa}$. $\bigcirc$ : points where the strain rates reach the minimum. where the magnitude of the circumferential strain acceleration begins to increase.
約 10 倍大きいことが注目される。

(3)クリープ制御開始時のひずみと両点までの経過時間＼cjkstart封 圧が $20 \mathrm{MPa}$ の場合についてはデータが少ないが，10 MPa の場 合については, クリープ制御開始時の軸ひずみと軸ひずみ速度最 小点までの経過時間の対数とは, 直線的な関係を示した (Fig. 8)。

一方，周方向についても，クリープ制御開始時の周ひずみと周 ひずみ速度最小点, または, 周ひずみ加速度増加開始点までの経 過時間の対数との間に直線的な関係が認められる。Fig. 9 はそ の一例を示したものであるが，封圧依存性は小さい。

(4)クリープ制御開始時のひずみとひずみ速度最小点やひずみ 加速度増加開始点におけるひずみ 軸ひずみ速度最小点におけ る軸ひずみは，封圧が大きいほど大きく，また，クリープ制御開 始時のひずみが大きいほど大きくなっている（Fig. 10）。

一方, 周ひずみ速度最小点における周ひずみについては, 封圧 依存性がみられず，クリープ開始時のひずみにも依存していない (Fig. 11)。周ひずみ加速度増加開始点における周ひずみについ ても, ばらつきは大きいものの, 同様の傾向が認められる (Fig. 12)。

\section{$2 \cdot 5$ 完全応カーひずみ線図}

通常の三軸試験（木山他, 1994）において, 軸ひずみが最大荷 重の約 $80 \%$ まで荷重にほぼ比例して増加し最大荷重点を経てク ラス II 挙動を示すこと, 周ひずみの大きさは最大荷重の約 $50 \%$ まで荷重にほぼ比例して増加した後急増すること, また, 最大荷 重点における軸ひずみ（限界圧縮ひずみ, 藤井他, 1994）は封庄 の増加に伴い大きくなるが, 同点における周ひずみの大きさは封
圧に依存しないことなどを明らかにした。

載荷をクリープ制御の後に周ひずみ速度一定制御に切り替えた 場合にも，軸ひずみはクラス II 挙動をし（Fig. 13(a)), 周ひず みも通常の三軸試験と類似した軌跡をたどることがわかった (Fig. 13(b))。封压・クリープ応力に鈍感な周ひずみ速度最小点 や周ひずみ加速度増加開始点における周ひずみの大きさの平均值 は, それぞれ通常の三軸試験における限界引張ひずみの平均値の $95 \%, 115 \%$ となり略一致している。

\section{3. 砂岩のクリープ試験}

気乾・湿潤の両状態で単軸クリープ試験を行った。また, 一部 については, 周ひずみ速度最小点の前や後で載荷をクリープ制御 から定ひずみ速度制御に切り替え, 得られた結果を通常の単軸圧 縮試験結果と比較した。さらに, 通常の単軸圧縮試験において最 大荷重点から除荷したときの応力ーひずみ曲線の軌跡とクリープ 試験における周ひずみ速度最小点や周ひずみ加速度増加開始点と の位置関係についても検討した。

なお, 得られた軸ひずみは前章で述べた試験よりもさらに S/ $\mathrm{N}$ 比が悪かったために解析の対象から除いた。

\section{$3 \cdot 1$ 供試体と試験方法}

上砂川炭鉱寒沢露天坑より採取した上砂川砂岩（古第三系中粒 砂岩) を直径 $30 \mathrm{~mm}$, 長さ $60 \mathrm{~mm}$ の円柱形に整形した後, 恒温 槽内にて $80{ }^{\circ} \mathrm{C}$ の温度で 24 時間乾燥し, デシケーター内に 1 か 月以上放置してから試験に供した (気乾状態)。また, 気乾状態 の供試体を水道水中に 24 時間浸した後, 表面の水滴をウェスで 


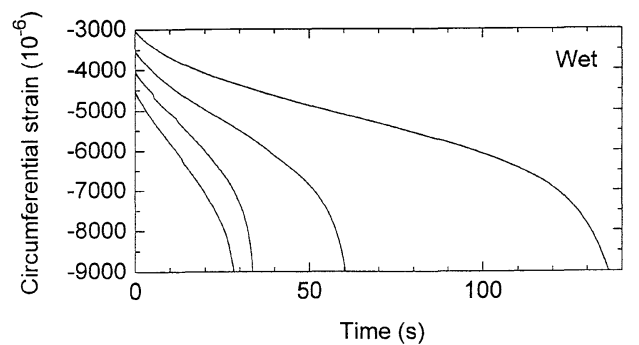

Fig. 14 Example of circumferential strain-time curve for wet specimens of Kamisunagawa Sandstone.

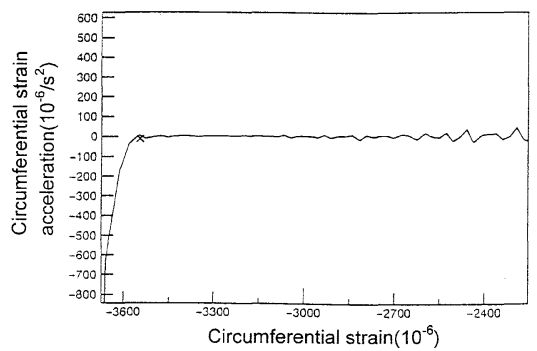

Fig. 15 Circumferential strain acceleration vs. circumferential strain for Kamisunagawa Sandstone in the uniaxial creep tests. $x$ : point where the acceleration magnitude begins to increase.

拭い直ちに試験に供した（湿潤状態）。含水による重量増加の割 合は約 $3 \%$ であった。供試体の被覆を行わなかったため, 試験 終了時には乾燥により最大で $1 \%$ の重量減少があった。

単軸載荷には Instron 社製材料試験機（5586 型，定格荷重 300 $\mathrm{kN}$ ，機械式）を用いた。ひずみは試験開始直前を基準とし，同 社製の伸び計（ゲージ長 $25 \mathrm{~mm}$ ，定格 $\pm 1 \mathrm{~mm}$ ）とチェーン式 周方向伸び計（定格 $\pm 5 \mathrm{~mm}$ ）を用いて軸ひずみ，周ひずみを測 定した。

載荷は，最初， $0.3 \mathrm{~mm} / \mathrm{min}$ の軸変位一定速度で制御し，周ひ ずみが $-1,000 〜-5,000 \times 10^{-6}$ に達した時点でクリープ制御に 切り換えた。荷重とひずみは $500 \mathrm{~Hz}$ の周波数でサンプリングし， 周ひずみに $40 \times 10^{-6}$ 以上の差異が現れたときのみハードディ スクに記録した。

なお，通常の単軸圧縮試験で得た単軸圧縮強度，ならびに，限 界引張ひずみの平均值は，気乾状態でそれぞれ $72.5 \mathrm{MPa} ， 4,831$ $\times 10^{-6}$ ，湿潤状態でそれぞれ $23.1 \mathrm{MPa}, 6,389 \times 10^{-6}$ であった (それぞれ供試体 4 本の平均值)。

\section{$3 \cdot 2$ 周ひずみ速度最小点や周ひずみ加速度増加開始点の特}

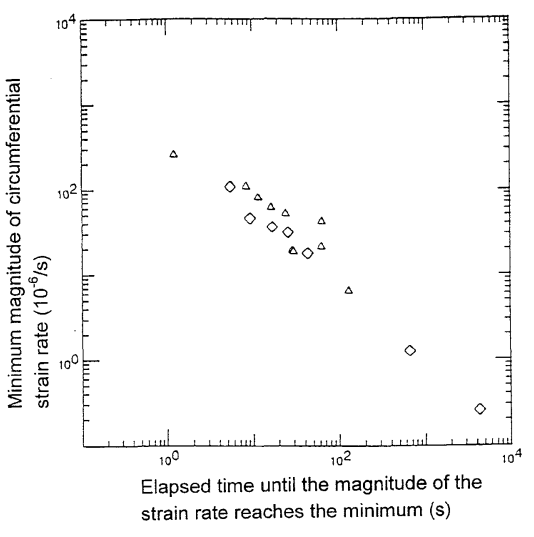

Fig. 16 The minimum magnitude in the circumferential strain rate vs. elapsed time until the magnitude of the strain rate reaches the minimum for Kamisunagawa Sandstone. Symbols $\diamond$ and $\Delta$ denote 'dry' and 'wet', respectively.

徵

稲田花崗岩の場合と同様に, 周ひずみには 1 次， 2 次，3 次ク リープが現れ（Fig. 14），また，周ひずみ速度最小点や周ひずみ 加速度増加開始点（Fig. 15）を明瞭に識別することができた。

(1)クリープ応力と両点までの経過時間クリープ応力と周 ひずみ速度最小点までの経過時間の対数との関係は, 気乾・湿潤 の両状態とも, 直線で近似できることがわかった。周ひずみ加速 度増加開始点についても, 気乾状態のデータが少ないものの, 同 様な結果が得られた。

(2)周ひずみ速度の大きさの最小值と周ひずみ速度最小点まで の経過時間 周ひずみ速度の大きさの最小值とそれが達成され るまでの経過時間との関係は, 気乾・湿潤状態に関わりなく, 両 対数座標において傾きが約 -1 の直線で近似できることがわかっ た (Fig. 16)。

(3)クリープ制御開始時の周ひずみと両点までの経過時間 クリープ制御開始時の周ひずみと周ひずみ速度最小点までの経過 時間の対数に関する測定結果は, 直線の周りにばらついているが, 気乾・湿潤状態の影響は大きくないようにみえる（Fig. 17）。同 じ傾向は，周ひずみ加速度増加開始点についても認められた。

(4)クリープ制御開始時の周ひずみと両点における周ひずみ

周ひずみ速度最小点におけるひずみの大きさは気乾状態の方が 湿潤状態と比べてやや小さい (Fig. 18)。また, 気乾・湿潤のい ずれの状態についても，このひずみはクリープ制御開始時の周ひ

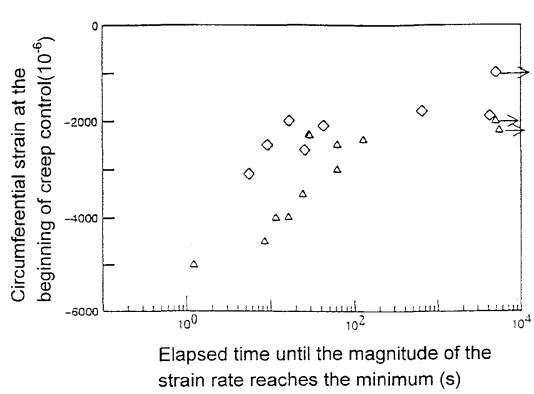

Fig. 17 Circumferential strain at the beginning of creep control vs. elapsed time until the magnitude of the strain rate reaches the minimum for Kamisunagawa Sandstone. Symbols $\rightarrow, \diamond$ and $\triangle$ denote 'not fractured', 'dry' and 'wet', respectively.

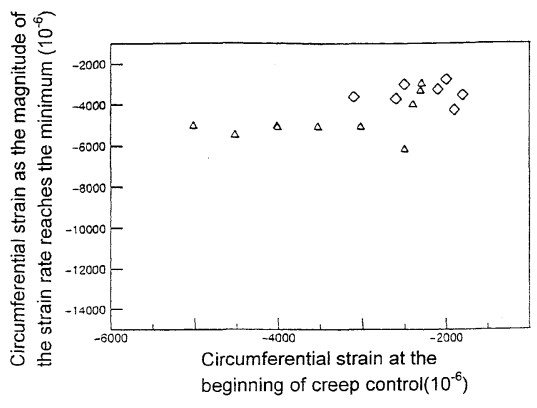

Fig. 18 Circumferential strain at the beginning of creep control vs. circumferential strain as the magnitude of the strain rate reaches the minimum for Kamisunagawa Sandstone. Symbols $\diamond$ and $\triangle$ denote 'dry' and 'wet', respectively.

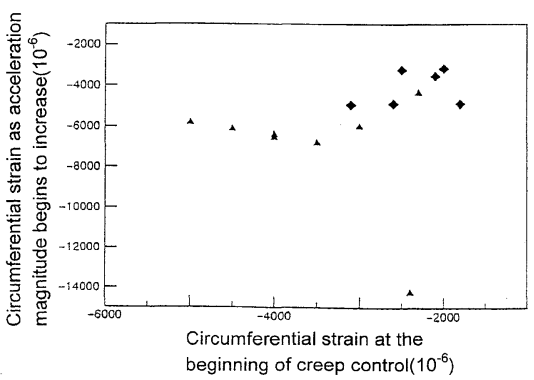

Fig. 19 Circumferential strain at the beginning of creep control vs. circumferential strain as the acceleration magnitude begins to increase for Kamisunagawa Sandstone. Symbols and $\boldsymbol{\Delta}$ denote 'dry' and 'wet', respectively. 


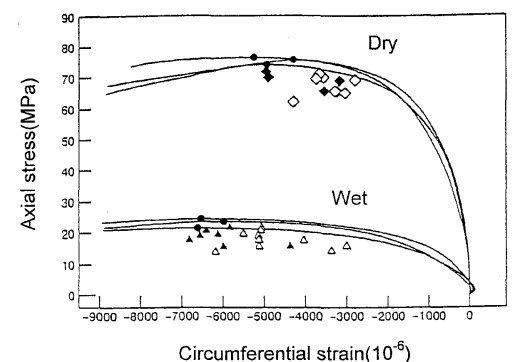

Fig. 20 Axial stress-circumferential strain curves in the uniaxial compression tests for Kamisunagawa Sandstone. : maximum load point. In this figure, the points at which the magnitudes of circumferential strain rate reach the minimum $(\triangle, \diamond)$ and the magnitude of the circumferential strain acceleration begin to increase $(\boldsymbol{\Delta}, \boldsymbol{\Delta})$ obtained in the creep tests are also shown.

ずみに依存していない。周ひずみ加速度増加開始点におけるひず みについても，ばらつきは大きいものの同様の傾向が認められる (Fig. 19)。

\section{$3 \cdot 3$ 単軸圧縮試験とクリープ試験における応カ一周ひずみ の関係}

通常の単軸圧縮試験下の最大荷重点における周ひずみの大きさ として定義される限界引張ひずみの值は, 気乾状態の方が湿潤状 態に比べてやや小さい(Fig. 20)。

周ひずみ速度最小点における周ひずみの大きさは, ばらつきは あるものの, 気乾・湿潤状態に関わらず限界引張ひずみよりも小 さい。一方, 周ひずみ加速度増加開始点における周ひずみに関し ては，気乾状態では限界引張ひずみにほぼ等しいデータとこれよ りやや小さいデータがある。湿潤状態では 1 つのデータを除いて 限界引張ひずみに略一致している。

\section{$3 \cdot 4$ 気乾状態における再載荷試験と除荷試験}

上記のクリープ試験に供したのとは異なるブロックを用いて供 試体を作製し，気乾状態における単軸圧縮試験，単軸クリープ試 験ならびに標記 2 試験を行った。クリープ試験では, 前節までと 同様な結果が得られた。一定の軸ひずみ速度制御下の単軸圧縮試 験に抢ける限界引張ひずみの平均值は $3,180 \times 10^{-6}$ であった。

(1)再載荷試験 $\quad 0.3 \mathrm{~mm} / \mathrm{min}$ の軸変位速度で軸圧の載荷を 行い, 周ひずみが $-1,000 〜-1,800 \times 10^{-6}$ に達した時点でクリー プ制御に切り換え，周ひずみが $-1,500 〜-4,000 \times 10^{-6}$ に達し た時点で変位を一旦止めた後, 初回の一軸載荷時と同じ軸変位速 度で再載荷した。

試験の結果，周ひずみ速度最小点や周ひずみ加速度増加開始点 に達する前に再載荷した場合には, 荷重は増加し, 単軸圧縮試験 と同じ大きさの最大荷重点がみられた（Fig. 21(a))。また, 最 大荷重点に扔ける周ひずみの大きさが限界引張ひずみに等しいこ とがわかった。

一方, これらの点に達した後に再載荷した場合には, 荷重の増 加はほとんどみられなかった（Fig. 21(b)，なお，この知見は， Yamashita et al., 1994 が軸ひずみ速度最小点について最初に 見出したものである)。試験に供したいずれの供試体についても， 再載荷開始時の周ひずみの大きさは既に限界引張ひずみを越えて いた。

(2)除荷試験 一定の軸変位速度で軸載荷し, 周ひずみの大 きさが，限界引張ひずみの平均值に達した時点で除荷した。この とき得られた載荷一除荷曲線の内の除荷部分は, クリープ試験に おける周ひずみ加速度増加開始点のデータが分布している領域を

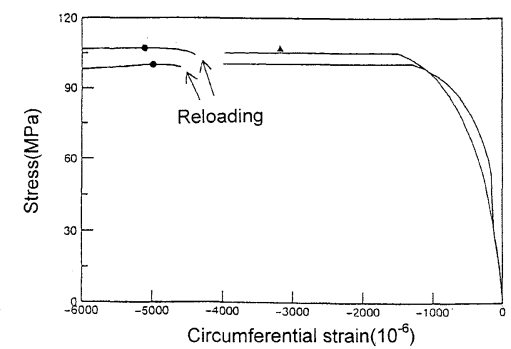

(b)

Axial stress-circumferential strain curves in the reloading tests on Kamisunagawa Sandstone. The reloading is carried out before (a) and after b) the magnitude of the circumferential strain rate reaches the minimum. : the maximum load points appeared in the reloading process, : the average maximum load points in the constant strain rate tests.

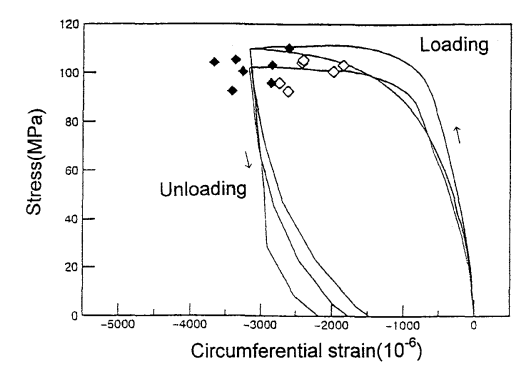

Fig. 22 Axial stress-circumferential strain curves in the loading and unloading tests for Kamisunagawa Sandstone. In this figure, the points at which the magnitude of the circumferential strain rate reaches the minimum $(\diamond)$ and the magnitude of the circumferential strain acceleration begins to increase $(\bullet)$ obtained in the uniaxial creep tests are also shown.

通り，同試験における周ひずみ速度最小点は同曲線の内側に分布 していた。すなわち, 周ひずみ速度最小点より, 周ひずみ加速度 増加開始点の方が, 最大荷重点により接近している (Fig. 22)。

\section{4. 考}

本章では, 応力・ひずみの各成分が岩石損傷を表す指標として どの程度有効かについて比較・検討する。また, 周ひずみ速度最 小点や周ひずみ加速度増加開始点の工学的意義について考察する。

\section{$4 \cdot 1$ 岩石損傷の指標}

本文 2.，3．や既報（藤井他，1994，1995）の結果を踏まえ， 環境依存性が小さく, 単独で岩石損傷の指標となり得る応力・ひ ずみ成分を探してみる。

(1)軸応力 定ひずみ速度試験における最大軸応力は, 封圧, 含水状態, ひずみ速度等に依存すること, クリープ強度は載荷時 間の関数になっていること等が知られている。これらは, 軸応力 単独で岩石損傷の程度を表すのは無理なことを示している。なお, 軸応力を差応力に置き換えても同様のことがいえる。

(2)軸ひずみ 定ひずみ速度試験における最大荷重点の軸ひ ずみの大きさは封圧に依存する。また, 本クリープ試験において も, ひずみ速度最小点における軸ひずみの大きさは, クリープ応 力や封圧に依存することがわかった。以上から, 軸ひずみについ ても単独で岩石損傷の指標とはなり得ないことがわかる。

（3）周ひずみ定ひずみ速度試験で得られる最大荷重点の周 ひずみの大きさは乾燥状態には若干依存するものの封圧には依存 しないことがわかっている（藤井他, 1994, Fujii et al., 1994）。 クリープ試験においても周ひずみには同様の性質がある事が明ら かになった。荻野他（1996）は, 横ひずみと同方向の弾性波速度 
との間に密接な関係を見出している。また, 少なくとも本研究で 使用した供試岩石の範囲では, 周方向のクリープひずみの方が軸 方向よりも約 10 倍大きかった（Singhの場合は 5 倍，また，湿 潤状態の登別熔結凝灰岩の場合には両ひずみのオーダーが等しい という報告がある，佐々木他，1995）。以上より，周ひずみは， (1)環境に鈍感である一方，(2)岩石の損傷に敏感で変化量が大き い, という性質があり, 単独で岩石損傷の指標となり得る可能性 を有していると考えられる。さらに，鉱柱のはらみ出し（西松. 大久保, 1992) やエキステンソメーターにより計測される岩盤内 空洞の空洞壁面に垂直なひずみは横ひずみに対応していることに 注意すれば, 当該ひずみ成分は原位置測定が容易であり, 応用性 が高いことがわかる。

(4)体積ひずみ＼cjkstart周知のようにダイラタンシーは岩石損傷の 直接的な指示量である可能性がある（例えば，里他，1991）。し かしながら, 軸ひずみと 2 倍の周ひずみとの和として定義される 標記ひずみは, 軸ひずみと周ひずみとの中間的な環境依存性を有 するものと予想される。Kranz（1980）の結果はこれを裏付ける ものである。また, 原位置計測が困難である点で周ひずみよりも 応用性に欠けるという久点がある。

以上から，4つの量の中では周ひずみが，原理・応用の両面か ら, 岩石損傷の指標として最も優れていると判断される。

\section{$4 \cdot 2$ 周ひずみ速度最小点, 周ひずみ加速度増加開始点の工} 学的意義

ひずみ速度最小点は, 2 次クリープ区間の中程に位置し, クリー プ挙動はこの点を境に, 同点以前のひずみ速度の大きさが減少す る部分と, 同点以降のひずみ速度の大きさが増加する部分に二分 される。岩石は, 同点以前では安定に向い, 同点以降では不安定 に向っていると解釈することができる。この解釈が正しいとすれ ば, 岩盤の安定性を周ひずみ速度から評価することが可能と考え られる。これは, 西松・大久保 (1992) の考え方を周ひずみに拡 張したものといえる。

一方, 周ひずみ加速度増加開始点は, 3 次クリープ開始点の付 近に位置している。したがって, 岩盤の周ひずみ加速度の大きさ が増加を始めたら巨視的破壊が接近しているという判断基準を導 くことができる。周ひずみ加速度は明確な立ち上がりを示すので, 従来, 軸ひずみ一時間線図を基に目視により決めていた 3 次クリー プ開始点よりも客観的に評価することが可能である。

本研究の結果は, 実験室で行った短時間のクリープ試験から得 られたものであり, 上に述べたような岩盤の安定性評価方法を実 用化するには, 長期クリープ試験や原位置における実証試験の結 果を待たなければならない。

\section{5. 結}

稲田花崗岩を用いて三軸圧縮試験と封圧下の短時間のクリープ 試験を行い, また, 上砂川砂岩を用いて異なる乾燥状態下での単 軸圧縮試験, 短時間のクリープ試験, 再載荷試験および除荷試験 を行った。実験結果は, 定ひずみ速度試験における最大荷重点, クリープ試験における周ひずみ速度最小点, 周ひずみ加速度増加 開始点の 3 点に注目して整理した。

試験の結果得られた主な知見は以下のようである。

（1）クリープ開始時の周ひずみと周ひずみ速度最小点（周ひ ずみ速度の大きさが最小になる点）や周ひずみ加速度増加開始点
（周ひずみ加速度の大きさが増加を開始する点）までの経過時間 の対数との直線関係は, 稲田花崗岩の場合, 封圧に依存せず, 上 砂川砂岩の場合，乾燥状態に鈍感であった。

（2）上砂川砂岩のクリープ制御の途中で軸変位速度一定の制 御に切り替える場合, この切り換えを周ひずみ速度最小や周ひず み加速度増加開始点に達する以前に行うと荷重は増加し, 最大荷 重点における周ひずみの大きさは限界引張ひずみ（定ひずみ速度 試験に扔ける最大荷重点の周ひずみの大きさ）に等しかった。切 り替えをこれ以降に行うと, 荷重の増加はほとんどみられなかっ た。

（3）上砂川砂岩について, 最大荷重点付近から除荷するとき に得られる応力ー周ひずみ線図の軌跡は, 周ひずみ加速度増加開 始点の分布している領域を通った。

以上から，(1)周ひずみ速度最小点や周ひずみ加速度増加開始 点は, 定ひずみ速度試験に㧍ける最大荷重点と密接に対応してい る, (2)クリープ試験においても, 定ひずみ速度試験と同様, 周 ひずみの大きさは岩石の損傷を表す尺度になり得る, という考え を導いた。

謝辞秋田大学鉱山学部山下秀教授ならびに室蘭工業大学工 学部児玉淳一助手には貴重な助言をいただいた。また, 査読者の 一人には懇切な指導を受けた。ここに記して謝意を表する。

\section{引用文 献}

趙 顕・大久保誠介・福井勝則 $(1995)$ ：周圧下での三城目安山岩のクリープ, 資源と 素材, Vol. 111, No. 8, p. 543-548

Cogan, J. (1976) : Triaxial Creep Tests of Opohnga Limestone and Ophir Shale, Int. J. Rock Mech. Min. Sci. \& Geomech. Abstr., Vol. 15, p. 1-10

藤井義明・石島洋二 (1995)：岩石の最大荷重点における最小主ひずみの正確な評価に 関する研究，資源と素材，Vol. 111，No. 9, p. 601-606

藤井義明・木山 保・石島洋二 (1994)：引張ひずみ規準に関する研究, 資源と素材, Vol. 110, No. 3, p. $211-214$

Fujii, Y., Kiyama, T. and Ishijima, Y. (1994) : A New Criterion for Brittle Failure of Rock, Proc. MMIJ/AusIMM Joint Symp., Ube, Japan, p. 469-476

藤井義明・木山 保・石島洋二 (1995)：含水が限界引張ひずみに及はす寸影響について, 資源・素材学会平成 7 年度春季大会講演要旨集, p. 221

木山 保・ 中田雅夫·藤井義明 · 大森瑞搮 ·石島洋二 (1994)：稲田花こう岩の限界引 張ひずみと三軸クリープひずみ特性について, 資源・素材学会平成 6 年度春季大 会講演会講演要旨集, p. $101-102$

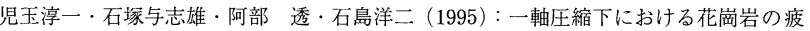
労・クリープ特性と長期強度, 資源と素材, Vol. 108, No. 3, p. 182-186

Kranz, R. (1980): The Effects of Confining Pressure and Stress Difference on Static Fatigue of Granite, J. Geophys. Res., Vol. 85, No. B4, p. 18541866

西松裕一 ·大久保誠介 (1992) : 釷柱の残存寿命の推定とその信頼性, 資源と素材, Vol. 108, No. 2, p. 141-145

荻野智成・福井勝則・大久保誠介 (1996) : 一軸圧縮試験における弾性波伝播特性の変 化, 平成 8 年度資源・素材学会春季講演会講演要旨集, p. 171

大久保誠介・西松裕一 (1986)：三城目安山岩と河津凝灰岩のクリープ特性と構成方程 式, 日本鉱業会誌，Vol. 102，No. 1181，p. 395-400

佐々木崇将・児玉淳一・後藤龍彦 (1995): 登別揢結凝灰岩の力学的性質に及ほすす含水 比の影響, 資源・素材学会北海道支部平成 7 年度春季講演会講演要旨集, p. 27

里 優・青木智幸・飯星 茂 (1991)：特にダイラタンシーに注目して行った岩石の 3 軸圧縮試験，土木学会論文集，Vol. 436, p. 73-82

Singh, D. P. (1975) : A Study of Creep of Rocks, Int. J. Rock Mech. Min. Sci. \& Geomech. Abstr., Vol. 12, p. 271-276

山下 秀·杉本文男 - 山内 優 $・$ 川辺金光 (1994) : 大谷石のクリープ特性とクリープ 過程について, 資源と素材, Vol. 110, No. 11, p. 875-882

Yamashita, S., Sugimoto, F., Yamauchi, M. and Mori, S. (1994) : Studies on Creep Process and Mechanism of Rock, Proc. MMIJ/AusIMM Joint Symposium, Ube, Japan, p. $341-350$ 